\title{
Epidemiology of cryptosporidiosis among European AIDS patients
}

\author{
C Pedersen, S Danner, A Lazzarin, M P Glauser, R Weber, C Katlama, S E Barton, \\ $\mathrm{J} D$ Lundgren, and the AIDS in Europe Study Group
}

Departments of

Infectious Diseases and

Gastroenterology,

Hvidovre Hospital,

Hvidovre, Denmark

C Pedersen

J D Lundgren

Academisch

Ziekenhuis bij de

Universitet van

Amsterdam,

Amsterdam,

Netherlands

$S$ Danner

Clinica Delle Malattie

Infettive, Universita di

Milano, Milano, Italy

A Lazzarin

Medecine 2-BH07, CHUV, Lausanne,

Switzerland

M P Glauser

Schweizerische HIV-

Kohortenstudie,

Koordinationszentrum,

Zurich, Switzerland

$\mathrm{R}$ Weber

Department de

Medicine Tropicale,

Hopital de la Pitie-

Salpêtrière, Paris,

France

C Katlama

Chelsea and

Westminster Hospital,

London, UK

$S$ E Barton

List of participants is

given in appendix $I$

AIDS in Europe Study

Group

Correspondence to:

Court Pedersen, The

EuroSIDA Coordinating

Centre, Department of

Infectious Diseases (144)

Hvidovre, Denmark.

Hvidovre, Denmark.

Accepted for public
1 December 1995

Objective: To study epidemiology and possible risk factors associated with the development of cryptosporidiosis among European patients with AIDS.

Methods: An inception cohort of 6548 patients with AIDS, consecutively diagnosed from 1979 to 1989, from 52 centres in 17 European countries was studied. Data on all AIDS defining events were collected retrospectively from patients' clinical records. Kaplan-Meier estimates, log rank tests and Cox proportional hazard models were used to examine for possible risk factors associated with cryptosporidiosis.

Results: Cryptosporidiosis was diagnosed in $432(6.6 \%)$ patients, 216 at time of the AIDS diagnosis and 216 during follow-up. The probability of being diagnosed with cryptosporidiosis at AIDS diagnosis was significantly lower for intravenous drug users $(1 \cdot 3 \%)$ than for homosexual men $(4 \cdot 1 \%)$ and for patients belonging to other transmission categories $(4.0 \%)(p<0.001)$. The probability was also higher for patients from Central Europe compared with patients from South Europe $(4 \cdot 1 \%$ versus $2 \cdot 5 \%, p=0 \cdot 005)$. The rate of developing cryptosporidiosis after the diagnosis of AIDS was 3 per 100 patient years of follow-up. The rate was significantly lower for intravenous drug users than for homosexual men (relative risk $0.34,95 \%$ confidence limits $0 \cdot 22-0.54$ ) and for women compared with men (RR $0.43(0.21-0.87))$. The risk was higher in North Europe than in South and Central Europe. In a multivariate analysis only transmission category remained a significant predictor for the development of cryptosporidiosis.

Conclusion: The development of cryptosporidiosis in AIDS patients may be associated with sexual risk behaviour.

(Genitourin Med 1996;72:128-131)

Keywords: cryptosporidia; cryptosporidiosis; epidemiology; HIV; AIDS

\section{Introduction}

Cryptosporidium is a protozoan parasite with worldwide distribution that has recently been shown to be a causative agent of diarrhoea in humans. In immunologically healthy persons it usually causes a selflimiting diarrhoea with full clinical recovery within a few weeks, ${ }^{1}$ whereas in patients with immune deficiency it may cause a severe, chronic diarrhoea that may be fatal because no effective antiparasitic treatment is available.

Cryptosporidiosis was one of the first recognised opportunistic infections in patients with the acquired immunodeficiency syndrome (AIDS), ${ }^{2}$ and cryptosporidium infection with diarrhoea lasting more than 30 days is part of the Centers for Disease Control (CDC) case definition of AIDS. ${ }^{3}$ Studies on the prevalence of cryptosporidiosis in AIDS patients have mostly been restricted to those with diarrhoea, or have been based on surveillance data. In studies of hospitalised AIDS patients with diarrhoea in Europe and the United States, between 11 and $21 \%$ of patients excreted cryptosporidium oocysts. ${ }^{4-7}$ In the developing world up to $48 \%$ of AIDS patients with diarrhoea has been reported to excrete oocysts. ${ }^{8-10}$ The frequency of cryptosporidiosis in AIDS patients at the time of AIDS diagnosis in developed countries is low, usually less than $3 \% .{ }^{11-14}$ However, these figures do not reflect the number of patients who will actually develop cryptosporidiosis at some time during their illness. ${ }^{15}$ In this paper we report on the epidemiology of cryptosporidiosis among European patients with AIDS, and on possible risk factors associated with the development of cryptosporidiosis.

\section{Materials and methods}

Information on AIDS cases seen at 52 centres across 17 European countries was collected by the multicentre study group on AIDS in Europe. Centres were only enrolled if they provided data on all patients diagnosed with AIDS at the centre between 1979 and 31 December 1989. The only exception was Italy where 23 centres enrolled a predefined fraction of their patients according to month of birth.

Information concerning AIDS defining illnesses at diagnosis and during follow-up, antiviral treatment, age, gender, probable transmission route, and CD4 cell count within 3 months of AIDS diagnosis were collected from the patients' medical records, using a standardised data collection form. Data related to dates of AIDS defining illnesses were recorded as month and year. Thus all diseases that occurred within 1 month of the AIDS diagnosis were recorded as present at time of diagnosis. Details of the study methods have been presented elsewhere. ${ }^{16}$ Cryptosporidiosis was defined as cryptosporidium infection with diarrhoea lasting at least 30 days. 
Table 1 Proportion of patients with cryptosporidiosis at time of AIDS diagnosis

\begin{tabular}{|c|c|c|c|}
\hline Variable & & $\begin{array}{l}\text { No with cryptosporidiosis/ } \\
\text { no at risk }(\%)\end{array}$ & Significance \\
\hline Sex & $\begin{array}{l}\text { Male } \\
\text { Female }\end{array}$ & $\begin{array}{c}200 / 5973(3 \cdot 4) \\
16 / 575(2 \cdot 8)\end{array}$ & NS \\
\hline \multirow[t]{2}{*}{ Transmission category } & $\begin{array}{l}\text { Homosexual men } \\
\text { Ivdu }\end{array}$ & $\begin{array}{r}161 / 3964(4 \cdot 1) \\
23 / 1774(1 \cdot 3)\end{array}$ & $\mathrm{p}<0.001^{\star}$ \\
\hline & $\begin{array}{l}\text { Other } \\
\text { Unknown }\end{array}$ & $\begin{array}{r}27 / 676(4 \cdot 0) \\
5 / 134(3 \cdot 7)\end{array}$ & $\begin{array}{l}\mathrm{p}<0.001^{\star} \\
\mathrm{p}=0.02^{\star}\end{array}$ \\
\hline Age (years) & $\begin{aligned}< & 30 \\
& 30-39 \\
> & 39\end{aligned}$ & $\begin{array}{l}65 / 2055(3 \cdot 2) \\
81 / 2565(3 \cdot 2) \\
70 / 1928(3 \cdot 6)\end{array}$ & NS \\
\hline Year of diagnosis & $\begin{array}{l}\leqslant 1986 \\
1987 \\
1988 \\
1989\end{array}$ & $\begin{array}{l}62 / 1588(3 \cdot 9) \\
42 / 1339(3 \cdot 1) \\
39 / 1626(2 \cdot 4) \\
73 / 1995(3 \cdot 7)\end{array}$ & NS \\
\hline Region & $\begin{array}{l}\text { South } \\
\text { Central } \\
\text { North }\end{array}$ & $\begin{array}{l}52 / 2088(2.5) \\
79 / 1948(4 \cdot 1) \\
85 / 2511(3 \cdot 4)\end{array}$ & $p=0.005 t$ \\
\hline Zidovudine pre-AIDS & $\begin{array}{l}\text { No } \\
\text { Yes }\end{array}$ & $\begin{array}{c}195 / 6059(3 \cdot 2) \\
21 / 489(4 \cdot 3)\end{array}$ & NS \\
\hline CD4 cell count & $\begin{array}{l}<50 \text { mill per microliter } \\
50-99 \\
100-149 \\
159-199 \\
\geqslant 200 \\
\text { Unknown }\end{array}$ & $\begin{array}{c}27 / 1086(2 \cdot 5) \\
20 / 583(3 \cdot 4) \\
7 / 351(2 \cdot 0) \\
2 / 276(0 \cdot 7) \\
22 / 750(2 \cdot 9) \\
138 / 3502(3 \cdot 9)\end{array}$ & NS \\
\hline Total & & $216 / 6548(3 \cdot 3)$ & \\
\hline
\end{tabular}

${ }^{\star}$ Compared with intravenous drug users (ivdu); †compared with South.

\section{Statistical methods}

Data were analysed using the Statistical Analysis System (SAS). Kaplan-Meier estimates, log rank tests and Cox proportional hazard models were used to examine factors associated with the development of cryptosporidiosis. Variables for which association with cryptosporidiosis was analysed included age ( $<30$ years, $30-40$ years, $>40$ years), gender, probable transmission route (homosexual men, intravenous drug users, other, unknown), year of diagnosis $(\leqslant 1986,1987,1988,1989)$, CD4 cell count at diagnosis $(<50,50-99$, $100-149,150-199, \geqslant 200$ per microlitre), zidovudine treatment before AIDS diagnosis, and region. Countries were classified into three regions; North (Denmark, Sweden, Finland, Netherlands, UK, Ireland, north Germany), central (Belgium, France, Luxembourg, Switzerland, south Germany) and south (Greece, Israel, Italy, Portugal, Spain).

Frequencies were compared by the chi square test.

\section{Results}

A total of 6548 patients was included in the study. Details on demographic factors have been presented previously. ${ }^{16}$ CD 4 cell counts measured around the time of AIDS diagnosis were available for 3046 patients.

Among the 6548 patients, 432 (6.6\%) were diagnosed with cryptosporidiosis, 216 at time of AIDS diagnosis and 216 during follow-up. The proportion of patients with cryptosporidiosis at time of AIDS diagnosis in the various subgroups of patients are shown in table 1 . The risk of being diagnosed with cryptosporidiosis was significantly lower for intravenous drug users compared with both homosexual men $(p<0.001)$ and the transmission category other $(p<0.001)$. The risk was higher for patients diagnosed in Central Europe compared with patients from Southern

Table 2 Comparison of frequencies of cryptosporidiosis among homosexual men and intravenous drug users (ivdu)

\begin{tabular}{|c|c|c|c|c|}
\hline \multirow[b]{2}{*}{ Variable } & & \multicolumn{2}{|c|}{ No with crypotsporidiosis/no at risk (percentage) } & \multirow{2}{*}{$\begin{array}{l}\text { Significance } \\
\text { (chi-square test) }\end{array}$} \\
\hline & & Homosexual men & $I v d u$ & \\
\hline Year of diagnosis & $\begin{array}{l}<30 \text { years } \\
30-39 \text { years } \\
>39 \text { years } \\
\leqslant 1986 \\
1987 \\
1988 \\
1989 \\
\text { South } \\
\text { Central } \\
\text { North }\end{array}$ & $\begin{array}{l}39 / 695(5 \cdot 6) \\
64 / 1708(3 \cdot 8) \\
58 / 1561(3 \cdot 7) \\
55 / 1183(4 \cdot 7) \\
28 / 835(3 \cdot 4) \\
24 / 906(2 \cdot 7) \\
54 / 1040(5 \cdot 2) \\
25 / 590(4 \cdot 2) \\
55 / 1170(4 \cdot 7) \\
81 / 2204(3 \cdot 7)\end{array}$ & $\begin{array}{c}14 / 1157(1 \cdot 2) \\
8 / 584(1 \cdot 4) \\
1 / 33(3 \cdot 0) \\
2 / 224(0 \cdot 9) \\
6 / 346(1 \cdot 7) \\
7 / 513(1 \cdot 4) \\
8 / 691(1 \cdot 2) \\
15 / 1305(1 \cdot 2) \\
8 / 359(2 \cdot 2) \\
0 / 109(0 \cdot 0)\end{array}$ & $\begin{array}{l}p<0.001 \\
p=0.004 \\
p=0.84 \\
p=0.009 \\
p=0.130 \\
p=0.111 \\
p<0.001 \\
p<0.001 \\
p=0.039 \\
p=0.042\end{array}$ \\
\hline
\end{tabular}

Table 3 Development of cryptosporidiosis during follow-up in patients without cryptosporidiosis at time of the AIDS diagnosis

\begin{tabular}{|c|c|c|c|}
\hline Variable & & $\begin{array}{l}\text { No with cryptosporidiosis/ } \\
\text { person years of follow-up (\%) }\end{array}$ & $\begin{array}{l}\text { Relative risk (95\% CI. } \\
\text { Unadjusted Cox } \\
\text { analysis) }\end{array}$ \\
\hline Sex & $\begin{array}{l}\text { Male } \\
\text { Female }\end{array}$ & $\begin{array}{c}208 / 6533(3 \cdot 2) \\
8 / 573(1 \cdot 4)\end{array}$ & $\begin{array}{l}1.00 \\
0.43(0.21-0.87)\end{array}$ \\
\hline Transmission category & $\begin{array}{l}\text { Homosexual men } \\
\text { Ivdu } \\
\text { Other } \\
\text { Unknown }\end{array}$ & $\begin{array}{c}178 / 4711(3 \cdot 8) \\
22 / 1625(1 \cdot 4) \\
14 / 657(2 \cdot 1) \\
2 / 114(1 \cdot 8)\end{array}$ & $\begin{array}{l}1.00 \\
0.34(0.22-0.54) \\
0.56(0.33-0.97) \\
0.46(0.11-1.83)\end{array}$ \\
\hline Age (years) & $\begin{aligned}< & 30 \\
& 30-39 \\
> & 39\end{aligned}$ & $\begin{array}{r}47 / 2254(2 \cdot 1) \\
112 / 2925(3 \cdot 8) \\
57 / 1927(3.0)\end{array}$ & $\begin{array}{l}0.46(0.11-1.83) \\
1.00 \\
1.82(1.30-2.56) \\
1.40(0.95-2.06)\end{array}$ \\
\hline Year of diagnosis & $\begin{array}{l}\leqslant 1986 \\
1987 \\
1988 \\
1989\end{array}$ & $\begin{array}{l}66 / 1879(3.5) \\
48 / 1629(2 \cdot 9) \\
44 / 1838(2 \cdot 4) \\
58 / 1760(3 \cdot 3)\end{array}$ & $\begin{array}{l}1.29(0.90-1.85) \\
0.98(0.66-1.43) \\
0.76(0.51-1.12) \\
1.00\end{array}$ \\
\hline Region & $\begin{array}{l}\text { South } \\
\text { Central } \\
\text { North }\end{array}$ & $\begin{array}{r}34 / 1633(2 \cdot 1) \\
62 / 2361(2 \cdot 6) \\
120 / 3112(3 \cdot 9)\end{array}$ & $\begin{array}{l}0.51(0.35-0.75) \\
0.69(0.47-0.94) \\
1.00\end{array}$ \\
\hline Zidovudine pre-AIDS & $\begin{array}{l}\text { No } \\
\text { Yes }\end{array}$ & $\begin{array}{c}200 / 6768(3.0) \\
16 / 468(3.4)\end{array}$ & $\begin{array}{l}1.00 \\
1.06(0.64-1.76)\end{array}$ \\
\hline CD4 cell count & $\begin{array}{l}<50 \text { per microliter } \\
50-99 \\
100-149 \\
150-199 \\
>=200 \\
\text { Unknown }\end{array}$ & $\begin{array}{c}27 / 1025(2 \cdot 6) \\
20 / 600(3 \cdot 3) \\
7 / 381(1 \cdot 8) \\
2 / 322(0 \cdot 6) \\
22 / 1098(2 \cdot 0) \\
138 / 3681(3 \cdot 7)\end{array}$ & $\begin{array}{l}1.25(0.71-2.22) \\
1.55(0.84-2 \cdot 80) \\
0.87(0.37-2.05) \\
0.29(0.07-1.24) \\
1.00 \\
\mathrm{ND}\end{array}$ \\
\hline
\end{tabular}


Europe $(p=0.005)$. There was no significant difference between men and women. The risk was not affected by previous zidovudine treatment, and there was no change over time. The influence of transmission category was consistent in subgroups of patients (table 2).

For patients without a diagnosis of cryptosporidiosis at time of AIDS, the subsequent rate of developing cryptosporidiosis was estimated to be 3.0 per 100 person years of followup (table 3). The rate of developing cryptosporidiosis was significantly higher for men than for women, and significantly lower for intravenous drug users and patients belonging to the transmission category other than for homosexual men. The rate was higher in Northern Europe compared with Central and Southern Europe, and patients aged 30-40 years had a higher rate than patients $<30$ years old and patients $>40$ years old. In a multivariate analysis only transmission category remained a significant predictor of the risk of cryptosporidiosis.

\section{Discussion}

We found a significant association between cryptosporidiosis and the mode of acquisition of HIV infection. There was a threefold increase in the risk among homosexual men compared with intravenous drug users, both at time of AIDS diagnosis and during follow-up. The difference was present within all regions, age groups and was independent of year of diagnosis. This suggests that transmission is associated with homosexual behaviour, probably reflecting that faecal-oral contact may be more common among homosexual men.

Our finding is consistent with a previous report of spread of cryptosporidium to sexual partners, ${ }^{17}$ and with an American study of HIV related diseases among outpatients in New York that showed that cryptosporidiosis had been diagnosed in $4.0 \%$ of homosexual men with AIDS compared with only $1 \cdot 1 \%$ of intravenous drug users with AIDS. ${ }^{18}$

Several waterborn outbreaks of cryptosporidiosis have been reported, ${ }^{19-21}$ and there is no doubt that waterborn transmission is very important globally. It is possibly that the quality of drinking water varied from country to country in our study, but this does not explain the difference between homosexual men and intravenous drug users, since the groups had similar access to city-furnished water. Only one Hungarian centre (29 patients) in general advised their patients to drink bottled water or to boil drinking water. Other possible explanations for a higher frequency of cryptosporidiosis among homosexual men, including increased exposure through travelling, different food habits, and sharing household with people infected with cryptosporidia, can not be excluded from the present data. It is possible that the use of opiates among intravenous drug users somewhat may protect against the development of symptomatic cryptosporidiosis, but this is unlikely to explain the observed difference since opiates usually have only temporary effect in cryptosporidiosis. We also found a higher frequency of cryptosporidiosis among AIDS patients with "other" or unknown risk behaviour compared with intravenous drug users, but these data should be interpreted cautiously, since these groups consist of a mixture of people infected through blood or blood products, heterosexuals, and probably also several undeclared homosexual or bisexual men.

Both nosocomial and waterborn outbreaks of cryptosporidiosis suggest that it is highly contagious, and only a low dose of cryptosporidium is necessary to establish infection in the immunocompromised host. ${ }^{22-23}$ In Denmark, 18 of $60 \mathrm{HIV}$ seropositive inpatients developed cryptosporidiosis after exposure to ice from an icemachine contaminated with cryptosporidium..$^{23}$ In the light of this high transmission rate it may seem surprising that the incidence of cryptosporidiosis has remained stable over time among European AIDS patients. There may be several explanations for this. First, sexual practices among homosexual men have changed during the 1980s making the risk of faecal-oral transmission of enteric pathogens less likely. According to this we have observed a pronounced decline in the proportion of homosexual men infected with Giardia lamblia and Entamoeba histolytica from 1985 to 1990 (personal unpublished data). Secondly, our data only reflect the incidence rate of symptomatic, AIDS defining cryptosporidiosis. It is possible that the prevalence of cryptosporidium infection among HIV infected patients with less impairment of immune function has changed over time. Since these patients may have spontaneous recovery or even be asymptomatic carriers, cryptosporidium infection is less likely to be diagnosed. Thirdly, AIDS patients with severe impairment of immune function may be less likely to engage in high-risk sexual practices involving faecal-oral contact. Finally, our results may have been biased by differences in diagnostic practices between regions and changes in practices over time. However, if this bias was significant, a rise in the incidence of cryptosporidiosis would have been expected due to better diagnostic procedures and greater clinical awareness.

Since no cure is available for cryptosporidiosis, our data suggest that HIV infected persons who have significant immune deficiency should refrain from sexual practices involving a risk of fecal-oral contact, should avoid close contact to farm animals, and should consider using bottled water or boiling their drinking water if they live in an area where drinking water may be contaminated with cryptosporidium oocysts. HIV infected persons participating in the caretaking of AIDS patients with cryptosporidiosis, as hospital staff, friends or family, should take special precautions against transmission of enteric pathogens.

\section{Appendix}

The multicentre study group on AIDS IN EUROPE (national coordinators in parenthesis) was as follows: Belgium (N Clumeck), S DeWit, B Sommereijns, Saint-Pierre Hospital, Brussels. Denmark (J O Nielsen), J 
Lundgren, T Nielsen, C Pedersen, Hvidovre Hospital; G Jensen, Frederiksberg Hospital; P Skinhøj, K Bentsen, J Gerstoft, M Melbye, Rigshospitalet, Copenhagen. Finland (A Ranki), S-L Valle, University Central Hospital, Helsinki. France (C Katlama), P Berlureau, Hospital de la Pitié-Salpétrière, Paris. Germany (M Dietrich), S Schwander, Bernhard-Nocht-Institut, Hamburg; F-D Goebel, Medizinische Poliklinik, Munich. Greece (J Kosmidis) Athens General Hospital; G Stergiou, T Gouzia, A Papadopoulos, 1st IKA Hospital, Athens. Hungary (D Banhegyi) Postgraduate Medical School, Budapest. Ireland (F Mulcahy St James's Hospital, Dublin. Israel (I Yust) Ichilov Hospital, Tel Aviv; Z BenIshai, Rambam Medical Center, Haifa: Z Bentwich, Kaplan Hospital, Rehovot; T Sacks, S Maayan, Hadassah University Hospital, Jerusalem. Italy (S Vella, A Chiesi) Istituto Superiore di Sanita, Rome: F Ancarani, G Scalise, Università di Ancona, Ancona; A Bertaggia, E Francavilla, Osp. Civile, Padova; G Calonghi, Arcispedale S. Maria Nuova, Regio Emilia; A Cargnel, Osp. Sacco, Milano; M Arlotti, R Ciammarughi, Osp. Infermi Rimini, Rimini; A Colomba, Osp. Casa del Sole, Palermo; F DeLalla, Osp. Civile, Vicenza; P Fassio, OO.RR. di Bergami, Bergami; A Ferlini, Osp. Infermi Faenza, Faenza; F Fiaccadori, G Pasetti, Osp. Riuniti, Parma; F Giannelli, Osp. Niguarda cà Granda, Milano; W Grillone, Osp. Amedeo di Savoia, Torino; A Lazzarin, A D'Arminio Monforte, Osp. L. Sacco, Milano; E Mignani, Osp. S. Andrea, La Spezia; A Nunnari, Patologia Medica Università, Catania; L Ortona, Università Cattolica del Sacro Cuore, Rome; G Panichi, Università di Sassari, Sassari; S Pauluzzi, Policlinico Monteluce, Perugia; N Piersantelli, Osp. Galliera, Genova; S Ranieri, Osp. S. Maria delle Croci, Ravenna; P Ricciardiello, Osp. Maggiore, Novara; B Roscioli, Osp. S. Maria Maddalena, Trieste; M Soranzo, Osp. Amedeo di Savoia, Torino. Luxembourg ( $R$ Hemmer), Centre Hospitalier, Luxembourg. Netherlands (S Danner), Peter Reiss, Academisch Ziekenhuisbij de Universitet van Amsterdam. Portugal (F Antunes), Hospital Santa Maria; R Proenca, Hospital Curry Cabral, Lisbon. Spain (J González-Lahoz), Rosa Polo, Instituto Carlos III, Madrid; B Clotet, Hospital Germans Trias i Pujol, Barcelona; J Gatell, E Buira, J Miró, Hospital Clinic I Provincial, Barcelona. Sweden (P Pehrson), Karolinska Insitutet, Stockholm. Switzerland (R Lüthy), B Ledergerber, C Olsson, Swiss HIV cohort study, Zürich; M Glauser, Centre Hospitalier Universitaire Vaudois, Lausanne;
B Hirschel, Hospital Cantonal Universitaire de Geneve, Geneve. United Kingdom (A Johnson), S Hawkes, A Phillips, UCL Medical School; S Barton, J Morcinek, St Stephen's Clinic, Chelsea and Westminster Hospital; A Pinching, D Coleman, St Mary's Hospital, London. Coordinating centre staff: I Gjørup, J Lundgren, J Nielsen, C Nieport, C Pedersen, L Teglbjaerg, A Thornval. The European Commission was the primary sponsor of this
study. The Danish Medical Research Council $(90-1295)$ and study. The Danish Medical Research Council (90-1295) and the Fondo de Investigaciones Sanitarias
(FIS 92/0415) also provided funding.

1 Soave R, Armstrong D. Cryptosporidium and cryptosporidiosis. Rev Infect Dis 1986;8:1012-3.

2 Navin TR, Juranek DD. Cryptosporidiosis: clinical, epidemiologic, and parasitologic review. Rev Infect Dis 1984 6:313-27.

3 Centers for Disease Control. Revision of the CDC surveillance case definition for acquired immunodeficiency syndrome. $M M W R$ 1987;36:1S-15S.

4 Smith PD, Lane HC, Gill VJ, et al. Intestinal infections in patients with the acquired immunodeficiency syndrome. patients with the acquired immun

5 Antony MA, Brandt LJ, Klein RS, et al. Infectious diarrhea in patients with AIDS. Dig Dis Sci 1988;33:1141-6.

6 Conolly GM, Dryden MS, Shanson DC, et al. Cryptosporidial diarrhea in AIDS and its treatment. Gut 1988;29:593-7.

7 Rene E, Marche, Regnier B, et al. Intestinal infections in patients with acquired immunodeficiency syndrome: a prospective study in 132 patients. Dig Dis Sci 1989;34: 773-80.

8 Sewankambo N, Mugerwa RD, Goodgame R, et al. Enteropathic AIDS in Uganda. AIDS 1987;1:9-13.

9 Colebunders R, Lusakumuni K, Nelson AM, et al. Persistent diarrhea in Zairean AIDS patients. Gut 1988; 29:1687-91

10 Malebranche RE, Arnoud E, Guerin JM, et al. Acquired immunodeficiency syndrome with severe gastrointestinal manifestations in Haiti. Lancet 1983;2:873-8.

11 Monforte A, Vago L, Lazzarin A, et al. AIDS-defining diseases in $250 \mathrm{HIV}$-infected patients; a comparative study of clinical and autopsy diagnosis. AIDS 1992;6:1159-64.

2 Selik RM, Starcher ET, Curran JW. Opportunistic disease reported in AIDS patients: frequencies, associations, and trends. AIDS 1987;1:175-82.

13 Turner BJ, Markson LE, McKee L, Houchens R, Fanning $T$. The AIDS-defining diagnosis and subsequent complications: a survival based severity index. $\mathcal{F}$ Acquired Immun Defic Syndr 1991;4:1059-71.

14 Pedersen C, Gerstoft J, Tauris P, et al. Opportunistic infections and malignancies in 231 Danish AIDS patients. tions and malignanci.

15 Blanshard C, Jackson AM, Shanson DC, Francis N, Gazzard BG. Cryptosporidiosis in HIV-seropositive patients. $Q \mathcal{F}$ Med 1992;85:813-23.

16 Lundgren JD, Pedersen C, Clumeck N, et al. Survival differences in European patients with AIDS, 1979-89. BMF 1994;308:1068-73.

17 Laughon BE, Druckman DA, Vernon A, et al. Prevalence of enteric pathogens in homosexual men with and without acquired immunodeficiency syndrome. Gastroenterology 1988;94:984-93.

18 Greenberg AE, Thomas PA, Landesman SH, et al. The spectrum of HIV-1 related disease among outpatients in New York City. AIDS 1992;6:849-59.

19 Clifford CP, Crook DWM, Conlon CP, et al. Impact of waterborn outbreak of cryptosporidiosis on AIDS and waterborn outbreak of cryptosporidiosis on AIDS
renal transplant patients. Lancet 1990;335:1455-6.

20 D'Antonio RG, Winn RE, Taylor JP, et al. A waterborn outbreak of cryptosporidiosis in normal hosts. Ann Intern Med 1985;103:886-8.

21 Richardson AJ, Frankenberg RA, Buck AC, et al. An outbreak of waterborn cryptosporidiosis in Swindon and Oxfordshire. Epidemiol Infect 1991;107:485-95.

22 Martino P, Gentile G, Caprioli A, et al. Cryptosporidium infection in renal transplant patients. $\mathcal{F}$ Infect Dis 1988 ; 158:647-8.

23 Ravn P, Lundgren JD, Kjaeldgaard $\mathrm{P}$, et al. Nosocomia outbreak of cryptosporidiosis in AIDS patients. $B M \mathcal{F}$ 1991;302:277-80. 